LICENÇA CC BY:

Artigo distribuído sob os termos

Creative Commons, permite uso e distribuição irrestrita em qualquer meio desde que o autor credite a fonte original.

\title{
ARTES DO CORPO E EDUCAÇÃO
}

\author{
Jean Carlos Gonçalves
}

Ángela Chaverra Brand

Tiago Mora Porteiro

Em nossas investigações, temos buscado articular o diálogo entre as Artes do Corpo e a Educação, temas emergentes e atuais para a pesquisa em ciências humanas, em uma perspectiva cuja centralidade das discussões recaia sobre os aspectos educacionais, de ordem teórica e/ou metodológica, relacionados ao tema em questão. Compreendendo o entrelaçamento entre as Artes do Corpo e a Educação por diferentes prismas investigativos, com demanda e alcance ainda pouco explorados por pesquisadores das áreas envolvidas, este dossiê pretende produzir reflexões sobre teorias e práticas educacionais transpassadas por corporeidade(s), performance(s), teatralidade(s), linguagem(ns) e estética(s), a fim de gerar contribuições para a ampliação da construção do conhecimento, instaurando novas possibilidades e abordagens para o enfrentamento dos temas levantados no que se refere à pesquisa científica em Educação.

Esse texto editorial é composto por três pequenos ensaios que procuram demonstrar o que temos compreendido sobre as relações entre Artes do Corpo e Educação, como organizadores desse dossiê, desde os países por nós representados: Brasil, Colômbia e Portugal. Agradecemos o convite da Revista Contrapontos para tal empreitada, aproveitando para recomendar a leitura deste número, destacando a significativa contribuição que os artigos ora publicados oferecem ao campo da pesquisa em Educação.

\section{Artes do Corpo e Educação, por Jean Carlos Gonçalves}

Embora os estudos do corpo em sua relação com as artes já possam se gloriar de uma certa trajetória, ainda não há consenso entre os pesquisadores sobre como nomear este campo de investigação. Ao colocá-lo em diálogo com a Educação, tornase necessário, então, a utilização de uma expressão que possa, ao menos, funcionar como chave epistêmica de leitura. É aí que, mesmo cientes das incertezas provocadas pelo tomo significativo que cabe no escopo das Artes do Corpo, escolhemos assim intitular este dossiê: Artes do Corpo e Educação. 
Discute-se de forma bastante profícua, no campo da Educação, as relações entre corpo e escola, corpo e movimento, corpo e cultura, no intuito de fazer avançar as reflexões sobre a área, sendo que ampla maioria das pesquisas provém do campo de conhecimento em Educação Física e, mais recentemente, dos Estudos de Gênero e Sexualidade. Sem descartar toda a amplitude e a necessidade de se fazer ciência considerando tais frentes investigativas, julgamos urgente pensar o lugar da discursividade do corpo em arte na pesquisa em educação. Importa, desse modo, expandir o que se sabe sobre arte (o que vai muito além da disciplina de Arte), sobre corpo (o que vai muito além de qualquer disciplina ou de qualquer pertencimento do corpo a uma área de estudo) e sobre Educação (o que vai muito além dos contextos escolares e da análise de práticas e processos).

Relacionar Artes do Corpo e Educação é, antes de tudo, uma tentativa de realizar perguntas. É despir-se de qualquer indício de veracidade ou autoridade quanto às formas ou aos meios de produção, circulação e recepção de discursos e saberes sobre o tema. Colocamonos, então, no lugar privilegiado daqueles que ainda querem aprender, daqueles que aceitam o seu próprio amadorismo frente a essa viagem de aprendizado que é a vida. Que nossos corpos, corpos de artistas, de educadores, de estudantes, encontrem um tempo para a leitura dos excelentes artigos que compõem este dossiê, e neles possam repousar suas dúvidas, angústias e expectativas.

Em tudo permanece o prazer estético, esse prazer tão especial e único que leva a preencher o vazio que acompanha nossas rotinas, o tempo que, em sua passagem inexorável vai trazendo a morte. (AZEVEDO, 2016, p. 269).

\section{Artes del Cuerpo y Educación, por Ángela Maria Chaverra Brand}

Muchas propuestas contemporáneas presentan al arte como un flujo de vida que dista de las categorías en las que algunos insisten en eternizarlo. Lo enuncian desde un encuentro de fuerzas heterogéneas, ninguna de las cuales busca la linealidad o la interpretación, sino que se dan como población de intensidades y allí el cuerpo del artista toma otra condición.

La experiencia creativa del pensamiento artístico, es decir, una estética de la desorganización de la experiencia interpretativa, desborda los límites de la subjetividad y del juicio para desplegarse en el campo de batalla más próximo: el cuerpo. En este terreno, la vitalidad no organizada prolifera en el cuerpo haciendo pasar intensidades, produciendo y conectando fuerzas múltiples en un spatium inextenso. (Diaz, 2014, p. 73,74)

Esto implica una desorganización de un cuerpo que ha sido sometido por un poder que lo categoriza y lo aplana en una función lógica. Si bien en muchos estudios actuales, ha sido explorado y conceptualizado desde diferentes lugares, en algunos escenarios, todavía se fija en una mirada estructural, escindida del espíritu o de la mente. Es innegable que el cuerpo ha sido pensado en nuestras culturas como herramienta de la experiencia y estructurado bajo la función de correspondencia: ojos-ver, oído-oír. 
En el giro corporal que se pretende realizar desde ciertas prácticas artísticas y se expande el lugar que se le ha trazado históricamente, y, como lo plantea Antonin Artaud, este cambio de perspectiva implica hacerse un cuerpo sin órganos, lo que transforma la percepción corporal e igualmente la forma del pensamiento, las interpretaciones históricas, estéticas que están completamente alejadas del impulso vital, lo que involucra una postura frente a la pedagogía y al hacer educativo, puesto que se cuestionan los lugares de las ciencias o del saber para proponer acontecimientos que renueven la visión de la vida, de la ética, del arte que se tienen, en la necesidad de llamar a un pueblo que no existe todavía, como un acto pedagógico. Es un juego en el que se celebra la vida, que se erige bajo una propuesta de una estética lúdica, y para ello necesita ser parte de una estrategia en la que emergen diferentes fuerzas, potencias que ahogan lo uniforme y que permiten siempre la diferencia y la diversidad.

Si los organismos como lo presenta Artaud, dependen de una estructura gramática, sometida a una jerarquía unívoca, monoteísta, su propuesta del cuerpo sin órganos creará no solamente una grieta artística, sino también una grieta epistemológica que pondrá en evidencia un pensamiento atravesado por el orden, la mathesis y la categorización. Las consecuencias de la rebelión se marcarán profundamente en la piel del arte, los movimientos sociales, educativos y políticos, en una batalla contra una forma exclusiva de ver el mundo.

\section{Artes do Corpo e Educação, por Tiago Mora Porteiro}

Ao longo da história e nas diversas culturas muito variados têm sido os entendimentos sobre os conceitos de corpo, educação e artes. E é por isso que nunca chegaremos ao ponto de encontrarmos definições, tanto consentâneas como definitivas. Tomar posição implica questionar fundamentos, ideológicos e didáticos com os quais trabalhamos. Driblando a complexidade e para não deixarmos de balizar um ponto de vista: corpo entendido como materialidade que se constitui "paisagem" identitária tecida por alteridades, desejos e simbologias; educação não como processo de transmissão, mas, sobretudo, como espaço onde experiências e partilhas humanas podem ativar a curiosidade pelo conhecimento; e artes como universo onde se fabricam e se confrontam outros imaginários e utopias.

Cada um destes pressupostos rasga caminhos de atuação, mas não sendo eles definitivos, de cada vez que os questionamos, somos obrigados a re-construir e a re-parar em novas constelações. Porque de presente e de presenças no mundo estamos a tratar, não podemos deixar de sinalizar o momento atual, quando tudo parece desmoronar-se. Porque a arte também é o espaço do não saber, da dúvida e da disrupção, perguntamo-nos se não estamos justamente hoje a pisar um terreno, ainda mais fértil e pertinente, onde a ação artística pode emergir com maior acutilância e sagacidade. Urge encontrar novas lógicas de entender o planeta Terra, coabitar o mundo e do viver em sociedade. Até porque a invasão do virtual e do digital nos convida a distanciarmo-nos das dimensões mais simples e mais corpóreas da vida, como a troca do sensível, dos afetos e da inteligência emocional. Enfim, o que aqui estamos 
a valorizar implica uma desierarquização de como entendemos o que é conhecimento! É essa a esteira onde nos movemos e em que acreditamos e por isso mesmo achamos pertinente propor este tema para o dossiê desta revista. Cada artigo, à sua maneira, é um contributo nesta caminhada, que não pode ser trilhada sem resiliência e sem resistência e que nunca mais terá fim.

\section{Referências}

AZEVEDO, Sônia. Campo feito de sonhos: os teatros do SESI. São Paulo: Perspectiva, 2016.

DIAZ, Santiago. Arte y pensamiento en Gilles Deleuze. Una experiencia lúdico-estética más allá de la interpretación. Fedro, Revista de Estética y Teoría de las Artes. Número 13, 2014. pp. 70-78. Disponível em: <http://institucional.us.es/fedro/uploads/pdf/n13/diaz.pdf> Acesso em: 20 out 2020. 